\title{
Competing Interactions between Micro-RNAs Determine Neural Progenitor Survival and Proliferation after Ethanol Exposure: Evidence from an Ex Vivo Model of the Fetal Cerebral Cortical Neuroepithelium
}

\author{
Pratheesh Sathyan, Honey B. Golden, and Rajesh C. Miranda \\ Department Neuroscience and Experimental Therapeutics, College of Medicine, Texas A\&M Health Science Center, Texas 77843-1114
}

\begin{abstract}
The fetal brain is sensitive to a variety of teratogens, including ethanol. We showed previously that ethanol induced mitosis and stem cell maturation, but not death, in fetal cerebral cortex-derived progenitors. We tested the hypothesis that micro-RNAs (miRNAs) could mediate the teratogenic effects of ethanol in a fetal mouse cerebral cortex-derived neurosphere culture model. Ethanol, at a level attained by alcoholics, significantly suppressed the expression of four miRNAs, miR-21, $-335,-9$, and -153 , whereas a lower ethanol concentration, attainable during social drinking, induced miR-335 expression. A GABA $A_{A}$ receptor-dependent mechanism mediated miR-21, but not miR-335 suppression, suggesting that divergent mechanisms regulate ethanol-sensitive miRNAs. Antisense-mediated suppression of miR-21 expression resulted in apoptosis, suggesting that miR-21 is an antiapoptotic factor. miR-335 knockdown promoted cell proliferation and prevented death induced by concurrently suppressing miR-21, indicating that miR-335 is a proapoptotic, antimitogenic factor whose actions are antagonistic to miR-21. Computational analyses identified two genes, Jagged-1, a Notch-receptor ligand, and embryonic-lethal abnormal vision, Drosophila-like 2 (ELAVL2), a brain-specific regulator of RNA stability, as presumptive targets of three of four ethanol-sensitive micro-RNAs. Combined knockdown of miR-335, -21, and -153 significantly increased Jagged-1 mRNA. Furthermore, ethanol induced both Jagged-1 and ELAVL2 mRNA. The collective suppression of micro-RNAs is consistent with ethanol induction of cell cycle and neuroepithelial maturation in the absence of apoptosis. These data identify a role for micro-RNAs as epigenetic intermediaries, which permit teratogens to shape complex, divergent developmental processes, and additionally demonstrate that coordinately regulated miRNAs exhibit both functional synergy and antagonism toward each other.
\end{abstract}

Key words: cerebral cortex; miR-21; miR-335; miR-9; miR-153; fetal alcohol syndrome; Jagged-1; ELAVL2; apoptosis

\section{Introduction}

The fetal ventricular (VZ) and subventricular (SVZ) zones exhibit enormous mitotic activity for a restricted developmental period to generate the neurons of the cortical plate (Rakic, 1988; Takahashi et al., 1999; Yumiko and Fujio, 2002; Noctor et al., 2004). The tremendous growth in brain size during this period of neurogenesis is accompanied by enhanced sensitivity to the teratogenic actions of a wide array of environmental agents and drugs of abuse (Clarren et al., 1978; Watson et al., 1999; Yanai et al., 2004; Petersen et al., 2006).

Ethanol is a prototypic teratogen. Heavy ethanol consumption during pregnancy can lead to a persistent and stereotypic constellation of neural and other deficits, collectively termed fetal alcohol spectrum disorders (Jones and Smith, 1975; Streissguth and O’Malley, 2000; Sokol et al., 2003; Loock et al., 2005). The

\footnotetext{
Received Sept. 5, 2006; revised June 17, 2007; accepted June 26, 2007.

This work was supported by National Institutes of Health/National Institute on Alcohol Abuse and Alcoholism Grant AA13440 (R.C.M.). We thank Dr. Wei-Jung Chen for review of this manuscript, Dr. Gerald Frye for consultations and for the gift of Picrotoxin, and Drs. Cynthia Camarillo and Jane Miller for technical assistance.

Correspondence should be addressed to Rajesh C. Miranda at the above address. E-mail: rmiranda@tamu.edu. DOI:10.1523/JNEUROSCI.1269-07.2007

Copyright $\odot 2007$ Society for Neuroscience $\quad$ 0270-6474/07/278546-12\$15.00/0
}

severe end of the continuum [i.e., fetal alcohol syndrome (Jones and Smith, 1975)] is characterized by significant mental retardation, accompanied by features including microencephaly, diminution of cortical gray matter, loss of interhemispheric communicating tracts, and the presence of neuronal heterotopias (Clarren et al., 1978; Clarren, 1986; Riley and McGee, 2005). Using an in vitro model for the second-trimester cerebral cortical neuroepithelium, we showed that, surprisingly, ethanol does not induce cell death (Santillano et al., 2005; Prock and Miranda, 2007). Rather, ethanol induces cell proliferation, while depleting the neural epithelium of ABCG2, c-kit, Sca-1, and CD133positive stem-cell populations (Santillano et al., 2005). These data indicate that ethanol drives premature stem- to blast-cell maturation within the embryonic cortical epithelium. An important question is what biological control processes underlie the teratogen-mediated maturation of neural stem cells?

Micro-RNAs (miRNAs) are 18- to 25-nucleotide-long noncoding RNA molecules that are important regulators of mRNA transcript stability (Denli and Hannon, 2003) and gene translation (Ambros, 2001). The human genome is predicted to contain $\sim 800$ miRNAs (Bentwich et al., 2005). Although relatively few in number, these miRNAs are predicted to control a large propor- 
tion of the tissue- and cell-specific transcriptome (Krek et al., 2005; Lim et al., 2005), thereby regulating important biological processes, including mitosis, tissue-specific differentiation, and death (Croce and Calin, 2005). Some miRNAs maintain the pluripotent state of embryonic stem cells (Houbaviy et al., 2003), whereas others delay neuronal maturation (Krichevsky et al., 2003) or promote neuronal differentiation by suppressing the expression of non-neuronal mRNA transcripts (Conaco et al., 2006). Consequently, a teratogen that targets even a few miRNAs is likely to disproportionately influence development.

As a first step to identify candidate miRNAs that mediate the teratogenesis of ethanol, we maintained gestational day 12.5 (GD12.5) fetal mouse cerebral cortex-derived neuroepithelial cells as nonadherent neurospheres, cultured in defined control or ethanol-supplemented medium. We present data showing for the first time, to our knowledge, that miRNA expression is selectively sensitive to a teratogen, ethanol. Furthermore, we also present novel evidence showing that ethanol-sensitive miRNAs exhibit synergistic as well as antagonistic actions in regulating the survival, proliferation, and expression of maturation-associated genes in fetal cortical neuroepithelial cells.

\section{Materials and Methods}

\section{Isolation of fetal mouse cerebral cortical neural precursors}

Animals were maintained in the animal housing facility at Texas A\&M Health Sciences Center, College of Medicine. All animal procedures were approved by the University Laboratory Animal Care Committee. Neural precursors were obtained from the dorsal telencephalic vesicles (the structural precursor of the cerebral isocortical projection neurons) of GD12.5 C57BL/6 mouse fetuses according to previously published protocols (Santillano et al., 2005; Camarillo et al., 2007; Prock and Miranda, 2007). Care was taken to eliminate the surrounding meningeal tissue, as well as tissue precursors to the hippocampus and the underlying striatum. Precursor cultures were established at an initial density of $10^{6}$ cells in serum-free mitogenic media (DMEM/F12 (catalog \#11330-032; Invitrogen, Eugene, OR), $20 \mathrm{ng} / \mathrm{ml}$ bFGF (basic fibroblast growth factor; catalog \#13256-029; Invitrogen), $20 \mathrm{ng} / \mathrm{ml}$ hEGF human epidermal growth factor; catalog \#53003-018; Invitrogen), $0.15 \mathrm{ng} / \mathrm{ml}$ LIF (leukemia inhibitory factor; catalog \#L200; Alomone Labs, Jerusalem, Israel), ITS-X (insulin-transferrin-selenium-X) supplement (catalog \#51500-056; Invitrogen), $0.85 \mathrm{Us} / \mathrm{ml}$ heparin (catalog \#15077-019; Invitrogen), and $20 \mathrm{~nm}$ progesterone (catalog \#P6149; Sigma, St. Louis, MO). Neurosphere cultures are a well established model that replicates the in vivo development and maturation of neuroepithelial stem and progenitor cells (Ostenfeld and Svendsen, 2004). We showed previously that cortical neuroepithelial cells maintained as neurosphere cultures, express a variety of stem and progenitor markers (nestin, ABCG2, Sca-1, c-kit, and CD133) (Santillano et al., 2005), but differentiate readily into multipolar neurons after the withdrawal of mitogenic factors and addition of extracellular matrix (Camarillo et al., 2007). Neurospherederived neurons express similar functional properties to neurons derived from in vivo models (Pagani et al., 2006).

\section{Neurosphere cultures and alcohol treatment}

Cortical neurosphere cultures containing $\sim 2$ million cells were assigned to either a control, or an ethanol-treated group doses ranging from 60 $\mathrm{mg} / \mathrm{dl}(13 \mathrm{~mm})$ to $320 \mathrm{mg} / \mathrm{dl}(70 \mathrm{~mm})$, and treated for $24 \mathrm{~h}$ (to identify immediate effects of ethanol) or $5 \mathrm{~d}$ (to identify tissue adaptations to ethanol). Actual ethanol concentration in the culture medium was measured by gas chromatography. The particular doses of ethanol were chosen to reflect levels within ranges attainable during episodes of social drinking $(60 \mathrm{mg} / \mathrm{dl})$ or in chronic alcoholics $(320 \mathrm{mg} / \mathrm{dl}$ ) (Adachi et al., 1991). Furthermore, ethanol concentrations used in this study are expected to reflect levels actually attained by a fetus after maternal exposure (Gottesfeld et al., 1990). All experiments were performed with neurosphere cultures that were passaged $<15$ times. Additionally, cultures were exposed to methanol at $320 \mathrm{md} / \mathrm{dl}$ for $5 \mathrm{~d}$. Because the GABA type-A
$\left(\mathrm{GABA}_{\mathrm{A}}\right)$ receptor mediates many of ethanol's actions (Ma et al., 2001;

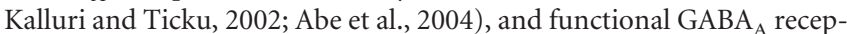
tors are present in fetal VZ neuroepithelial cells (Owens et al., 1999; Maric et al., 2001), we also used the $\mathrm{GABA}_{\mathrm{A}}$ antagonist picrotoxin (at 100 $\mu \mathrm{M})$ (Nakamura et al., 2007), to block the effects of ethanol in some experiments. In control experiments, neurosphere cultures were exposed to picrotoxin by itself (at $100 \mu \mathrm{M}$ ) for $5 \mathrm{~d}$ to mimic the duration of ethanol exposure.

miRNA isolation, microarray labeling, and hybridization miRNA fractions were isolated from cultured cells using mirVana miRNA Isolation Kit (Ambion, Austin, TX) according to the manufacturer's protocol. Purified miRNAs samples were quantified using the NanoDrop ND-1000 UV-Vis Spectrophotometer (NanoDrop Technologies, Wilmington, DE). miRNA expression at genome level was studied using micro-RNA microarrays (supplied by the Neuroscience Gene Expression laboratory, Rutgers University, Piscataway, NJ), containing probes for 845 mature miRNAs from five species (Goff et al., 2005). miRNA samples were labeled with the Array 900 miRNA-labeling and detection kit (Genispehere, Hatfiled, PA), and arrays were hybridized according to the manufacturers protocol. A total of five independent sample pairs were hybridized to five independent arrays. Additionally, a dye-flip experiment was performed on one pair of samples to estimate systematic dye bias. After hybridization, arrays were scanned using a GenePix 400B scanner (Molecular Devices, Union City, CA), and the scanner gain and sensitivity was set so that the overall ratio of Cy3 to Cy5 intensity across the array was set at 1 . Median spot intensities were determined using GenePix 4.0 (Molecular Devices). Array features that were irrelevant to the analysis, including blank features, Cy3 control spots, and miRNA probe features for all species except mouse, were removed before additional analysis. We further eliminated genes classified as "undetected," based on a univariate mixture modeling and Bayesian statistical modeling algorithm (Asyali et al., 2004; Asyali and Alci, 2005). The data were analyzed further using GeneSifter (VizX Labs, Seattle, WA). Because a minority of sampled miRNAs (84 of 218) were identified as "expressed" by the mixture-modeling algorithm, and because of the a priori possibility that ethanol could globally regulate miRNA expression, we did not further normalize the data. Spot intensity data were log-transformed, and analyzed using $t$ tests with Benjamini and Hochberg corrections for multiple comparisons.

\section{Real-time RT-PCR for miRNA and mRNA}

We validated our microarray data with real-time reverse transcription (RT)-PCR analyses for miRNAs, based on the protocol described by Schmittgen et al. (2004), and an SYBR green-based amplification detection, using a MyiQ single-color real-time PCR detection system (BioRad, Hercules, CA). Random hexamers were used for reverse transcription of miRNAs using the Thermoscript RT kit (Invitrogen) with $500 \mathrm{ng}$ of miRNA sample (primer sequences were as reported by Jiang et al. (2005). For analysis of gene expression, mRNA was reverse-transcribed into cDNA using Superscript III (Invitrogen), with $2 \mu \mathrm{g}$ of mRNA sample as a template. Primers to Jag-1 (Jagged-1; forward primer in exon-13, 5'-AAAGACCACTGCCGTACCAC-3'; reverse primer in exon-16, 5' TTCCTTTCCAGCCATTTTTG-3'; efficiency $112 \% ; r=0.988$ ), and embryonic-lethal abnormal vision, Drosophila-like 2 (ELAVL2; forward primer in exon-2, 5'-CACAGAG GACAGCAAGACCA-3'; reverse primer in exon-5, 5'-CCTCAATCCGCTTGTCA AAT-3'; efficiency $83 \% ; r=0.963$ ) were designed to cross intron-exon boundaries (Beacon Designer, version 4.0; Premier Biosoft International, Palo Alto, CA). Cyclophilin-A was used as a normalization control according to our previously published protocols (Santillano et al., 2005). Thermalstability analysis was performed to confirm the amplification of a single PCR product. RNA expression was quantified by calculating the difference between the cycle threshold of the miRNA, or mRNA of interest, and the normalization control [U6 small nuclear RNA $\left(\mathrm{U} 6_{\mathrm{SNR}}\right)$ or cyclophilin-A mRNA, respectively] for each sample [ $\Delta$ cycle threshold $(\Delta \mathrm{CT})]$, and data were expressed as $1 / 2^{\Delta \mathrm{CT}}$. Data that were assembled from multiple experimental plates were normalized to the mean $1 / 2^{\Delta \mathrm{CT}}$ expression value of the independent experimental controls within each 


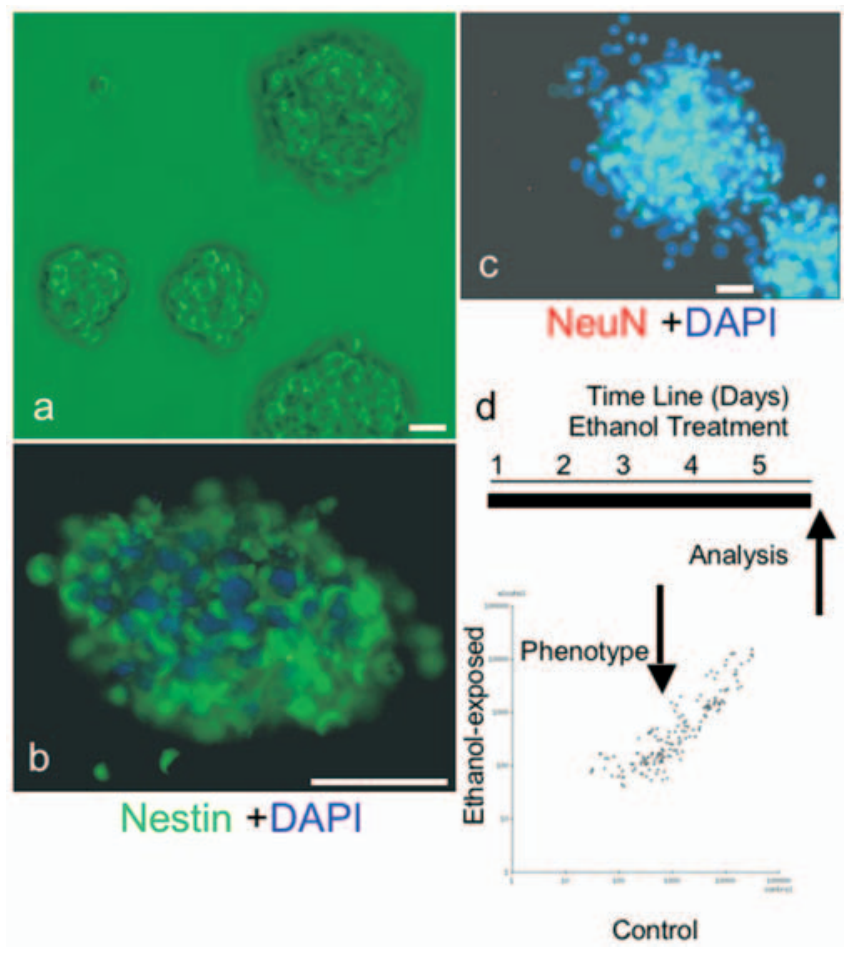

Figure 1. a, Mouseneocortical precursors isolated from GD12.5 fetal mice (see Materials and Methods) were grown as neurosphere cultures in mitogenic medium (+bFGF/+hEGF/+ LIF). $\boldsymbol{b}, \boldsymbol{c}$, Neurosphere cultures are immunopositive for nestin (fluorescein, green; $\boldsymbol{b}$ ). However, cultures lacked nuclear localization of NeuN (rhodamine, red; $c$ ), confirming the immaturity of neurospheres. Cell nuclei are counter-stained with DAPI (blue). $\boldsymbol{d}$, Schematic of experimental model depicting the temporal sequence of ethanol treatment and analysis. The scatter-plot depicts miRNA expression (fluorescence intensity) in control ( $x$-axis) and ethanol-treated ( $y$ axis) cultures. Data points represent mean values based on five independent replicates. Scale bars, $50 \mu \mathrm{m}$.

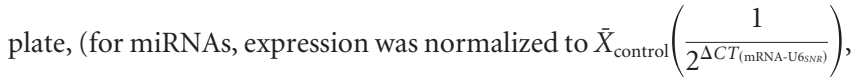
and for mRNAs expression was normalized to $\bar{X}_{\text {control }}\left(\frac{1}{2^{\left.\Delta C T_{\text {(mRNA-CydophilinA) }}\right)}}\right)$, where $\bar{X}_{\text {control }}=$ the control mean), and expressed as a percentage of the control mean.

miRNA loss-of-function analyses

Neurosphere cultures at a density of $10^{4}$ cells were transfected with $2^{\prime}$-Omethyl (2'OMe)-base modified miRNA antisense (Integrated DNA Technologies, Corvallis, OR) using Lipofectamine 2000 (Invitrogen). Based on a preliminary analysis, we used a concentration of $1.0 \mu \mathrm{M}$ each antisense. This concentration was not, by itself, cytotoxic. The miRNA antisense were based on the following sequences: $2^{\prime}$ OMe-EGFP (enhanced green fluorescent protein) nonsense control, 5' -AAGGCAAGCUGACCCUGAAGU-3'; 2'OMemiR-21, 5'-GUCAACAUCAG UCUGAUAAGCUA- $3^{\prime}$ [adapted from Chan et al. (2005)]; 2 'OMe-miR-335, 5' -ACA UUUUUCGUUAUUGCUCUUGA-3'; 2 'OMe-miR-153, 5'-GAUCACUUUUGUGACUAU GCAA$3^{\prime}$; and 2 'OMe-miR-9 (conserved across all members of the miR-9 family), 5'-UCAUACAGCUAGAUAACCAAAGA-3'. Cells were collected from these cultures at $7-24 \mathrm{~h}$ after transfection.

\section{Measurement of apoptosis}

Flow cytometry. Flow cytometry to measure DNA content in neurosphere cultures stained with Propidium iodide (50 $\mu \mathrm{g} / \mathrm{ml}$; Sigma) was conducted according to previously published protocols (Cheema et al., 2004; Santillano et al., 2005). A minimum of 10,000 cells from each sample were assayed. Cells with a less than $G_{0}$ DNA content were defined as apoptotic.

Microscopic evaluation of apoptosis. To visualize the DNA fragmentation characteristic of apoptosis, cells were stained with DAPI

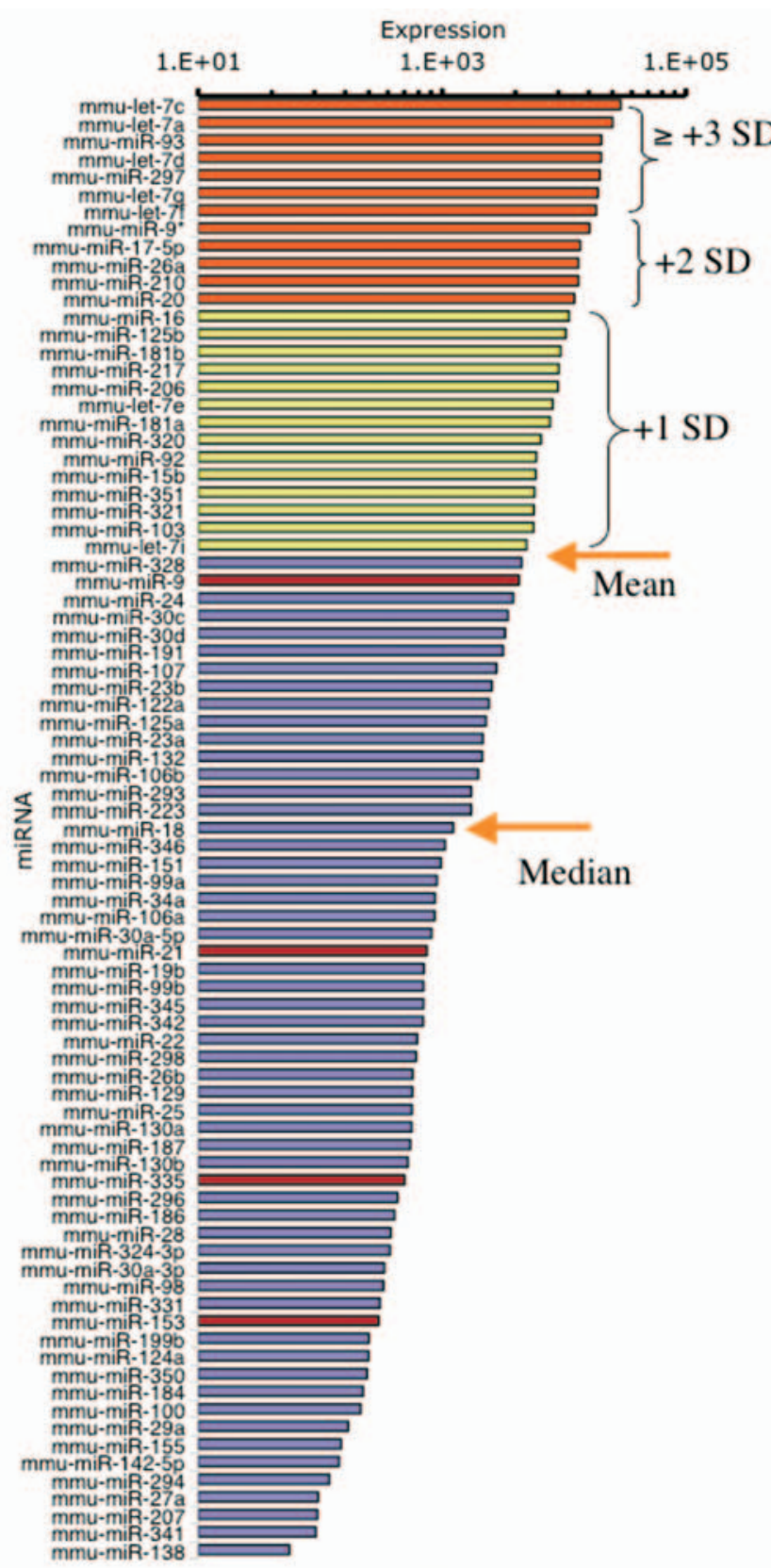

Figure 2. Histogram depicting the rank-ordered expression of miRNAs as a function of their abundance (mean microarray hybridization fluorescence intensity) in five independent control samples. Microarray data were first filtered using a univariate mixture-modeling algorithm (see Materials and Methods), to identify miRNAs that were reliably expressed in embryonic cortical neuroepithelial-derived neurosphere cultures. Filtered miRNAs were then rank ordered by their hybridization intensity. Orange arrows mark the mean and median hybridization intensities of the filtered miRNAs. The divergence between the mean and median intensity values indicates that there are a few miRNAs, from the let-7 family for example, that are highly overexpressed compared with a majority of other miRNAs. Yellow bars indicate miRNAs that are expressed at 1 SD above the mean intensity, whereas orange bars indicate expression at 2 or greater SDs above the mean intensity. Red bars denote miRNAs that were significantly suppressed by ethanol. The histogram indicates that ethanol targets the moderately expressed miRNAs, rather than the highly expressed miRNAs, in cortical neuroepithilal cells.

(4,6,diamidino-2-phenylindole) and nuclear DNA fragmentation was visualized by fluorescent microscopy on an Olympus (Tokyo, Japan) BX60 microscope.

LDH cytotoxicity assay. The lactate dehydrogenase ( $\mathrm{LDH})$ assay to measure cytotoxicity was performed according to our previously published protocols (Cheema et al., 1999; Wade et al., 1999). Briefly, culture- 

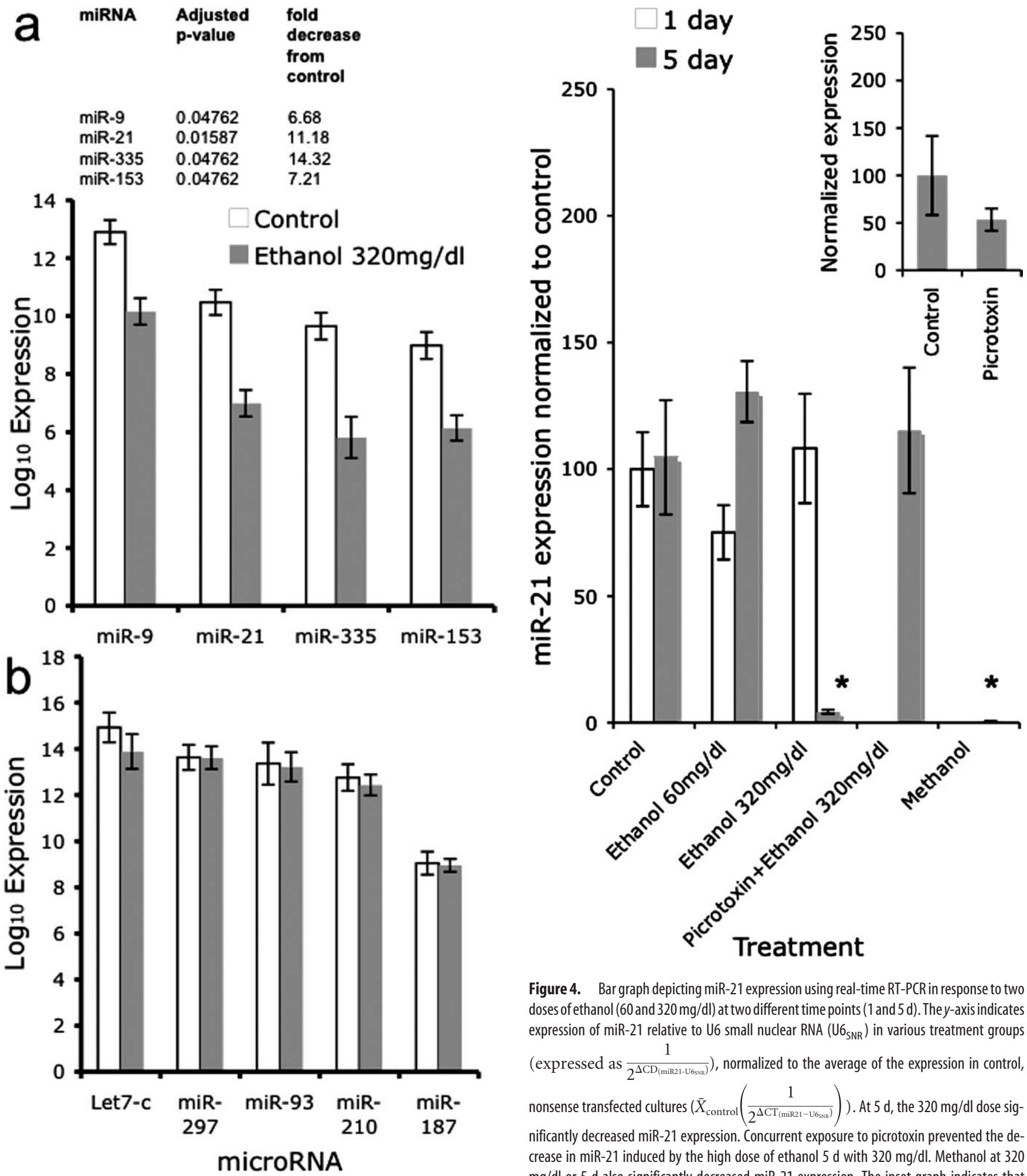

Figure 4. Bar graph depicting miR-21 expression using real-time RT-PCR in response to two doses of ethanol ( 60 and $320 \mathrm{mg} / \mathrm{dl}$ ) at two different time points ( 1 and $5 \mathrm{~d}$ ). The $y$-axis indicates expression of miR-21 relative to $\mathrm{U} 6$ small nuclear RNA $\left(U 6_{S N R}\right)$ in various treatment groups

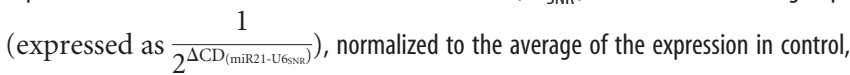
nonsense transfected cultures $\left(\bar{X}_{\text {control }}\left(\frac{1}{2^{\Delta C T_{\text {(miR21-U6ssa }}}}\right)\right)$. At $5 \mathrm{~d}$, the $320 \mathrm{mg} / \mathrm{dl}$ dose significantly decreased miR-21 expression. Concurrent exposure to picrotoxin prevented the decrease in miR-21 induced by the high dose of ethanol $5 \mathrm{~d}$ with $320 \mathrm{mg} / \mathrm{dl}$. Methanol at 320 $\mathrm{mg} / \mathrm{dl}$ or $5 \mathrm{~d}$ also significantly decreased miR-21 expression. The inset graph indicates that picrotoxin by itself (at $100 \mu \mathrm{m}$ for $5 \mathrm{~d}$ ) did not induce a statistically significant change in miR-21

Figure 3. Bar graphs depicting the expression of miRNAs in control and ethanol-exposed conditions. The $x$-axis depicts treatment conditions, whereas the $y$-axis depicts the $\log _{10}$ of the average signal intensity over five arrays. Data are expressed as mean \pm SEM. $\boldsymbol{a}$, Bar graphs depicting the mean intensity values of four microRNAs (miR-9, $-21,-335$, and -153) that were significantly suppressed by exposure to ethanol at $320 \mathrm{mg} / \mathrm{dl}$ for $5 \mathrm{~d}$. Inset, Adjusted (Benjamini and Hochberg correction for multiple comparisons) $p$ values and fold suppression of the statistically significant miRNAs. $\boldsymbol{b}$, Sample of high to moderately expressed miRNAs that are identified as expressed in cortical neuroepithelial cells, according to microarray analysis, but not targeted by ethanol. expression. Data were expressed as mean \pm SEM. Asterisks indicate statistical significance compared with controls; $p$ values are as indicated in the text.

conditioned medium was collected $7 \mathrm{~h}$ after transfection. Samples of culture medium were assayed for LDH activity using a kit (LDH assay kit; Roche, Welwyn Garden City, UK) and following the manufacturers instructions.

Caspase activation assay. A fluorimetric assay for the quantification of activated caspases $(2,3,6,7,8,9$, and 10 ; homogenous caspase assay; 


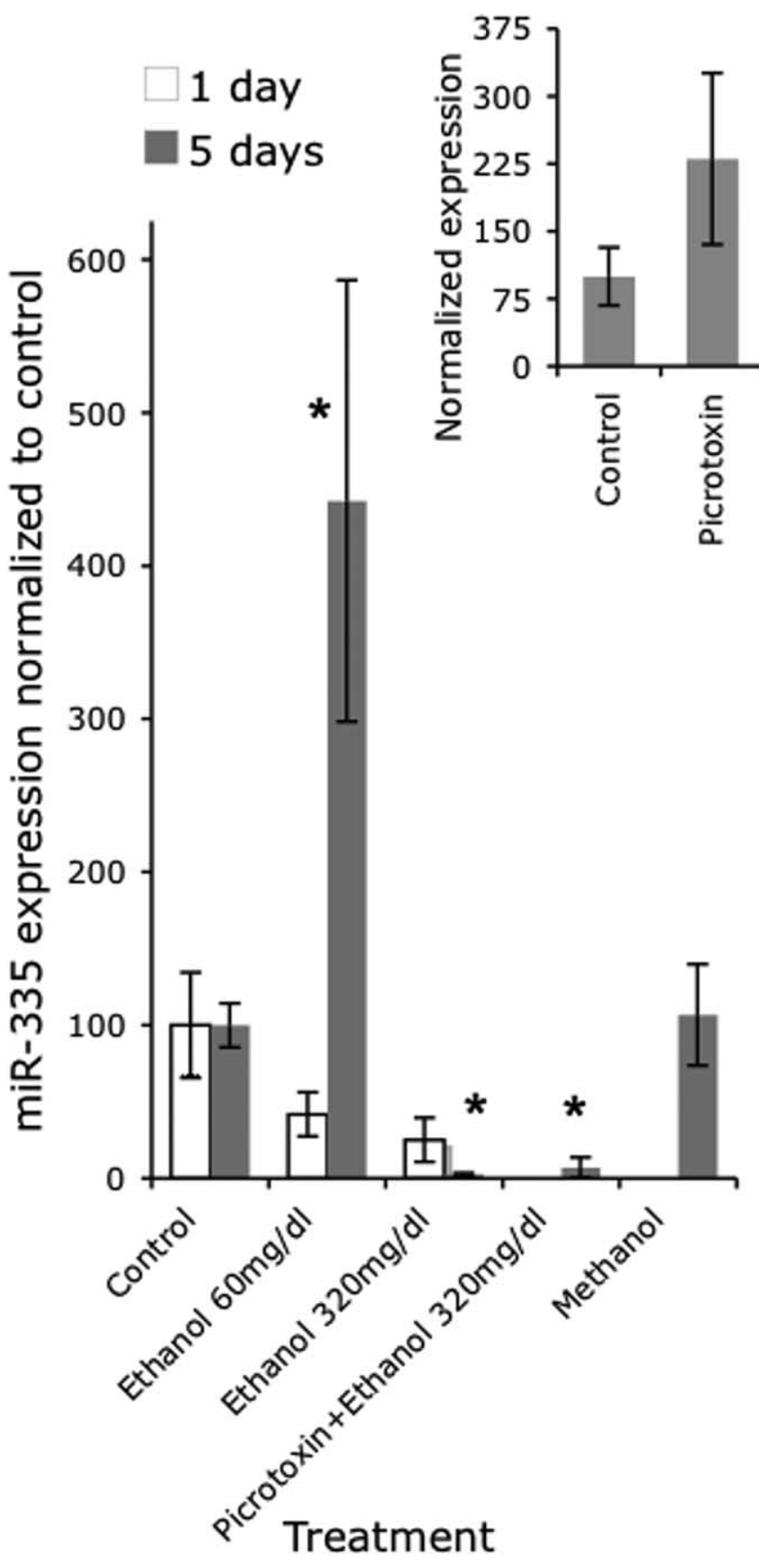

Figure 5. Bar graph depicting miR-335 expression using real-time RT-PCR in response two doses of ethanol ( 60 and $320 \mathrm{mg} / \mathrm{dl}$ ) at two different time points ( 1 and $5 \mathrm{~d}$ ). At $5 \mathrm{~d}$, the low dose caused a statistically significant induction, whereas the high dose caused a statistically significant suppression of miR-335 expression compared with controls. Concurrent exposure to picrotoxin did not prevent the suppression in miR-335 expression induced by the high dose of ethanol compared with controls. Methanol at $320 \mathrm{mg} / \mathrm{dl}$ for $5 \mathrm{~d}$ did not alter miR-335 expression. The inset graph indicates that picrotoxin by itself (at $100 \mu \mathrm{m}$ for $5 \mathrm{~d}$ ) did not induce a statistically significant change in miR-335 expression. The $y$-axis indicates normalized miRNA expression (expressed as $\frac{1}{\left.2^{\Delta \mathrm{CT}(\text { mir335-U6ss:) }}\right)}$ normalized to the mean expression in control cultures, as in Fig. 4). Data were expressed as mean \pm SEM. Asterisks indicate statistical significance compared with controls; $p$ values are as indicated in the text.

catalog \#3005372; Roche) was used to determine whether apoptosis occurred by a caspase-mediated mechanism. Independent samples containing a total of $10^{4}$ cells, collected $7 \mathrm{~h}$ after transfection with miR-21 antisense or nonsense control, were incubated in caspase substrate at $37^{\circ} \mathrm{C}$ for $3 \mathrm{~h}$. The cleavage of the substrate by activated caspase and the

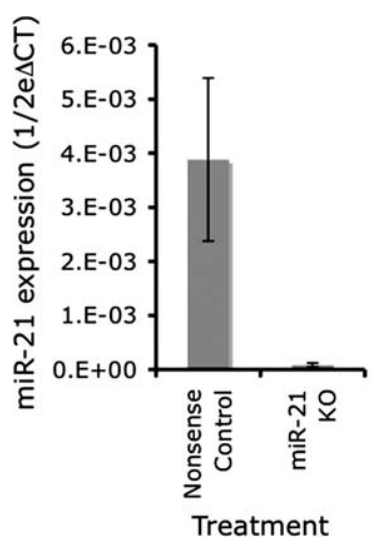

b

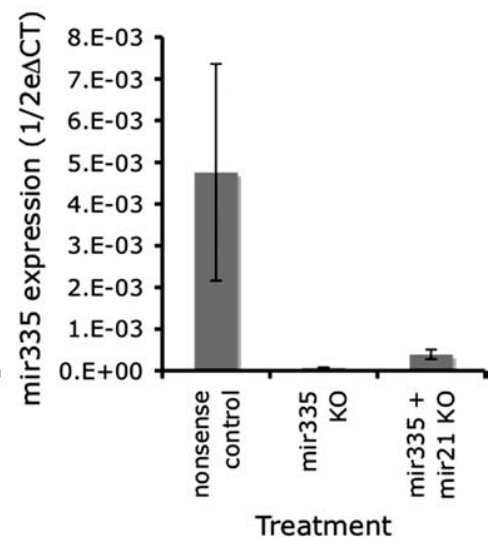

Figure 6. $\quad \boldsymbol{a}$, Real-time RT-PCR illustrating significant downregulation of miR-21 after miR-21 knockdown with antisense 2' 0 -methyl bases compared with control (nonsense oligonucleotide). The $y$-axis (expressed as $1 / 2^{\Delta C T}$ ) indicates miRNA expression in cultures, normalized to $U 6_{\mathrm{SNR}} \cdot \boldsymbol{b}$, Bar graph depicting miR-335 expression after either miR-335 knockdown alone, or in combination with miR-21 knockdown. miR-335 expression in the combined knockdown of miR-21 and miR-335 was similar to the expression after miR-335 knockdown alone. Data were expressed as mean \pm SEM.

release of fluorescence was determined fluorimetrically at $521 \mathrm{~nm}$ using a fluorescence microplate reader (FLX800; Bio-Tek Instruments, Burlingame, CA).

Cell proliferation assay. Changes in cell proliferation were measured using a colorimetric bromodeoxyuridine (BrdU)-based ELISA assay (Roche). Cells were exposed to BrdU, along with combinations of antisense to miRNAs of interest. Twenty-four hours after miRNA knockdown, culture medium was aspirated, and BrdU incorporation detected according to the manufacturer's protocol.

\section{Data analyses}

Microarray-derived data were analyzed by $\mathrm{T}$ tests with a Benjamini and Hochberg correction for multiple comparisons, using GeneSifter (VisX Labs, Seattle, WA). All other data were analyzed using SPSS software version 13 (SPSS, Chicago, IL). miRNA expression, verified by real-time RT-PCR, was analyzed by multivariate ANOVA (MANOVA) using Pillai's trace statistic, followed by post hoc univariate ANOVA, and Fisher's least significant difference (f-LSD) test. Other data were analyzed using ANOVAs followed by post hoc f-LSD using planned comparisons, or alternatively, by Student's $t$ tests for experiments entailing comparisons between two groups. In all cases, the $\alpha$ value was set at 0.05 . Data were expressed as mean $\pm \mathrm{SEM}$ or $\mathrm{SD}$, as indicated in the figure legends.

\section{Results}

For the following experiments, we modeled the embryonic cerebral cortical ventricular and subventricular zones using nonadherent neurosphere cultures derived from GD12.5 mouse fetal cerebral cortical neuroepithelium and cultured in defined medium (Fig. 1a). Cortical-derived neurosphere cultures express nestin (Fig. 1b), but not the neuronal nuclear antigen NeuN (Fig. 1c), indicating immaturity (Camarillo et al., 2007). Cultures were treated with control medium or with ethanol for $5 \mathrm{~d}$. We used a microarray platform (Goff et al., 2005) to profile miRNA expression in neurosphere cultures, and to compare miRNA expression in control and ethanol-treated (at $320 \mathrm{mg} / \mathrm{dl}$ ) cultures. This miRNA dataset has been deposited with the National Center for Biotechnology Information Gene Expression Omnibus (www. ncbi.nlm.nih.gov/geo/; accession number GPL-4229). We used a univariate, mixture-modeling algorithm (Asyali et al., 2004; Asyali and Alci, 2005) to identify miRNAs that were expressed in neurosphere cultures, and to eliminate nonexpressed miRNAs. 


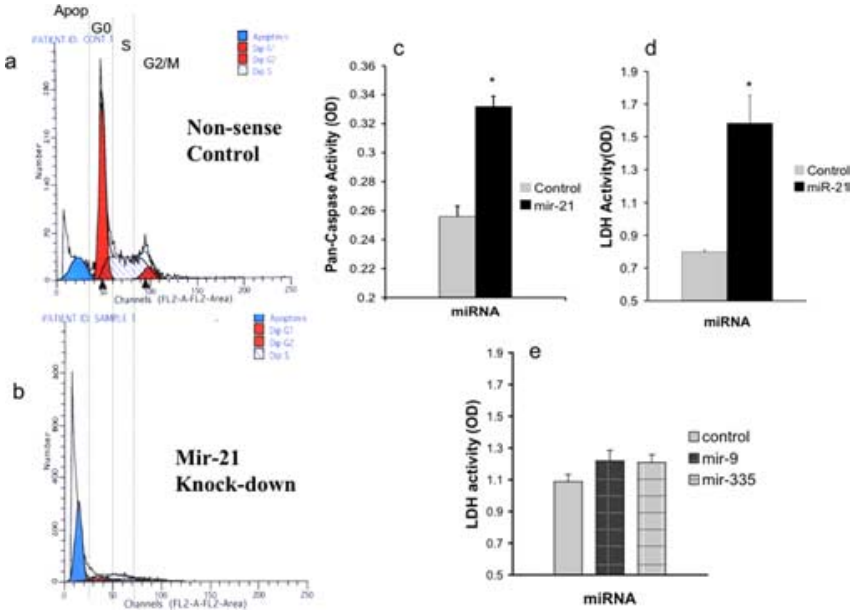

Figure 7. Frequency histograms representing flow cytometric analysis of DNA content. $\boldsymbol{a}, \boldsymbol{b}$, The $x$-axes represents fluorescence intensity caused by propidium iodide (PI) incorporation and the $y$-axes depicts cell frequency. Cultures were treated with nonsense $(\boldsymbol{a})$ or miR-21 antisense (b) for a period of $7 \mathrm{~h}$. Control, Nonsense oligonucleotide-treated cultures exhibit a peak cell frequency of PI incorporation at $G_{0}$, and peaks at $S$-phase and $G_{2} / M$, with greater than $G_{0} P I$ intensity. However, a low frequency of cells are observed with less than $G_{0}$ DNA content, indicative of a low level of apoptosis. In contrast, miR-21 antisense-treated cultures $(\boldsymbol{a})$ exhibit a large peak-frequency of cells at less than $\mathrm{G}_{0}$ DNA content, indicating that a majority of cells were apoptotic. c, A pan-caspase assay measuring the activation of a combination of initiator and executioner caspases (caspases 2, 3, 6, 7, 8, 9, and 10) shows that miR-21 knockdown significantly induced the activation of caspases. They-axis depicts a photometric [optical density (OD)] measurement of pan-caspase activity, whereas the $x$-axis depicts the experimental condition, transfection with nonsense control or antisense to miR-21. $\boldsymbol{d}$, LDH activity was measured as an alternate index of cell death, and showed that miR-21 knockdown significantly induced LDH release into the culture medium. The $y$-axis depicts photometric determination (expressed in $0 D$ units) of $L D H$ activity in culture medium, whereas the $x$-axis denotes the treatment condition. $\boldsymbol{e}$, Knockdown of miR-9 and miR-335 did not significantly alter LDH release and cell death compared with nonsense control. Each experiment was based on more than six independent replicates and data are expressed as mean \pm SEM. Asterisks indicate statistical significance compared with controls; $p$ values are as indicated in the text.

miRNAs were categorized as being expressed if, according to the algorithm, they exceeded expression criterion in at least $80 \%$ (four of five) of the arrays. The resulting log-transformed data, containing expressed miRNAs, were analyzed using the GeneSifter suite of programs (Fig. 1d). Neural epithelial cells maintained in neurosphere cultures express $\sim 40 \%$ of the sampled miRNAs (84 of 218) (Fig. 2). Among these, let-7c was the miRNA that was most highly expressed by cortical neurosphere cultures, and $72 \%$ (five of seven) of the most highly expressed miRNAs belonged to the let-7 family.

\section{Ethanol suppresses the expression of specific miRNAs during neurogenesis}

Figure $3 a$ lists the four miRNAs (miR-21, miR-335, miR- 9, miR$153)$ that were significantly regulated by a high dose of ethanol $(320 \mathrm{mg} / \mathrm{dl})$ after controlling for the false discovery rate (of a total of 23 miRNAs with a raw $p$ value $<0.05$ ). In comparison, other miRNAs throughout the range of expression intensities (Fig. 3b) were not regulated by ethanol, indicating that ethanol did not have a global effect on miRNA expression. With the exception of miR-9, which was ranked near the mean expression level for neural-expressed miRNAs (Fig. 2), ethanol did not regulate any of the highly expressed miRNAs. Rather, ethanol targeted the moderately expressed miRNAs. Interestingly, those ethanolsensitive miRNAs that achieved statistical significance (control- ling for the false discovery rate) were all suppressed, and none were upregulated after ethanol exposure.

Because our microarray data indicated that miR-21 and miR335 were the most highly suppressed by ethanol (11- and 14-fold, respectively), we analyzed the expression of these miRNAs by real-time RT-PCR at two different time points, using two different ethanol concentrations to model two different consumption patterns (to mimic levels that are attainable among social drinkers $(60 \mathrm{mg} / \mathrm{dl})$ and among chronic alcoholics $(320 \mathrm{mg} / \mathrm{dl})$ (Adachi et al., 1991). Multivariate analysis (Pillai's Trace Statistic) of our real-time RT-PCR data (Figs. 4,5$)$ indicate that there was a significant main effect of treatment $\left(F_{(8,94)}=6.15 ; p<0.01\right)$; and an interaction effect between treatment and time $\left(F_{(2,46)}=7.72\right.$; $p<0.01)$. Post hoc univariate ANOVA indicated a significant main effect of treatment on miR-21 and miR-335 expression $\left(F_{(4,47)}=3.54, p<0.01\right.$ and $F_{(4,47)}=9.8, p<0.01$, respectively $)$ and a significant interaction between treatment and time $\left(F_{(2,47)}\right.$ $=3.1, p<0.05$ and $F_{(2,47)}=15.1, p<0.01$, respectively). At $5 \mathrm{~d}$, the low dose of ethanol did not alter miR-21 expression, but the higher dose of ethanol resulted in a statistically significant ( post hoc f-LSD, $p<0.01$ ) 23-fold decline in miR-21 expression compared with controls. In contrast, the low dose of ethanol induced a statistically significant ( post hoc f-LSD, $p<0.01$ ) fourfold increase in miR-335 expression, whereas the high dose induced a statistically significant ( post hoc f-LSD, $p<0.01$ ) 38-fold decline in miR-335 expression compared with controls, consistent with the results of our microarray analyses.

Because many effects of ethanol are thought to be attributable to modulation of the $\mathrm{GABA}_{\mathrm{A}}$-receptor (Ma et al., 2001; Kalluri and Ticku, 2002; Abe et al., 2004), we examined whether a $\mathrm{GABA}_{\mathrm{A}}$ receptor antagonist, picrotoxin, could prevent the ethanol mediated suppression of miR-21 and miR-335. In a separate analysis, picrotoxin exposure by itself (for $5 \mathrm{~d}$ at $100 \mu \mathrm{M}$ ) did not induce a statistically significant change in miR-21 and miR-335 expression $\left[t_{(10)}=1.16\right.$, not significant (ns) (Fig. 4, inset) and $t_{(9)}$ $=1.56$, ns (Fig. 5, inset), respectively]. We also asked whether the effects of ethanol could be generalized to other alcohols. The overall MANOVA for these comparisons indicated a statistically significant effect (Pillai's trace statistic, $F_{(2,35)}=17.53 ; p<0.01$ ). ANOVA indicated an overall statistically significant effect of on both miR-21 $\left(F_{(3,36)}=5.86 ; p<0.01\right)$ and $\operatorname{miR}-335\left(F_{(3,36)}=\right.$ $4.54 ; p<0.01)$ expression. Our data show that picrotoxin prevented the ethanol-mediated suppression of miR-21 expression (Fig. 4), but did not prevent the decline in miR-335 expression produced by concurrent ethanol exposure (Fig. 5) (post hoc f-LSD, $p<0.05$ compared with controls). Furthermore, $5 \mathrm{~d}$ of exposure to another alcohol, methanol (at $320 \mathrm{mg} / \mathrm{dl}$ ), resulted in a significant decline in miR-21 expression (Fig. 4) (post hoc f-LSD, $p<0.01$ compared with controls), but not miR-335 expression (Fig. 5).

Because ethanol suppressed miR-21 and miR-335 expression, we set out initially to determine the cellular phenotype that resulted from suppression of these micro-RNAs using antisense technology. One micromolar antisense suppressed miR-21 expression by $\sim 32$-fold (Fig. $6 a$ ), whereas miR-335 exhibited up to $\sim 66$-fold suppression (Fig. 6b), as measured by real-time PCR. Combined knockdown of miR-21 and miR-335 did not alter the efficacy of the knockdown of miR-335.

\section{miR-21 suppression causes apoptotic cell death}

Between 7 and $9 \mathrm{~h}$ after transfection, we observed significant cell death, specifically in miR-21 antisense-treated cultures. Flow cytometric analysis of DNA content showed that there was an in- 
crease in the number of cells with less than $\mathrm{G}_{0}$ DNA content within $7 \mathrm{~h}$ after exposure to miR-21 antisense, compared with nonsense control (Fig. 7a,b), indicating increased apoptosis in miR-21 suppressed cultures. This apoptosis was accompanied by a significant increase in the activation of caspases, as measured by a pan-caspase assay $($ Fig. $7 c)\left(t_{(6)}=4.08 ; p<0.01\right)$. Finally, miR-21 antisense, but not nonsense control, significantly increased the release of LDH into the culture medium (Fig. $7 d$ ) $\left(t_{(10)}=4.6 ; p<0.01\right)$, indicating that $\mathrm{LDH}$ release was a marker for apoptotic cell death. Because of the overlap between LDH activity and other measures of apoptosis, we used LDH activity as a measure of cell death in subsequent experiments.

\section{Evidence for functional antagonism}

between miR-335 and miR-21

The proapoptotic effect of miR-21 suppression was at odds with our previous observations (Santillano et al., 2005) that ethanol did not induce apoptosis in cerebral cortical progenitors. However, because ethanol also suppressed the expression of other miRNAs, we examined the effects of suppressing $\mathrm{miR}$ 335, and miR-9 on cell death. Neither miR-9- nor miR-335 suppression significantly altered $\mathrm{LDH}$ release, compared with the nonsense control (Fig. 7e) (overall ANOVA, $F_{(2,33)}=1.77$, ns). However, cotransfection of miR-335 and miR-21 antisense significantly prevented the death caused by suppression of miR-21 (Fig. 8a) (overall ANOVA, $F_{(3,28)}=21.16, p<0.01$; post hoc f-LSD, $p<0.01$ compared with miR-21). Cotransfection of miR-9 along with miR-335 did not additionally prevent the cell death caused by miR-21 suppression. Morphological analysis of cultures stained with DAPI to visualize nuclei revealed nuclear disintegration and the presence of cytoplasmic nuclear fragments in miR-21 antisense- (Fig. $8 c, d$ ), but not nonsense control-treated (Fig. $8 b$ ) cultures. Concurrent treatment with miR-335 antisense, along with miR-21 antisense, prevented the nuclear fragmentation (Fig. 8e) observed after treatment with miR-21 antisense alone. These data suggest that the simultaneous suppression of miR-335 is the mechanism that renders neural progenitor cells resistant to death induced by miR-21 suppression.

Evidence for a role for $\mathrm{miR}-335$ in regulating cell proliferation

We observed previously that ethanol exposure increased cell proliferation in cortical neuroepithelial cells. We therefore tested whether suppressing miR-21, -335, and -9 separately, and in various combinations altered the nuclear incorporation of $\mathrm{BrdU}$ as a marker for cell cycle. Figure 9 shows that the suppression of miR-21 and - 9 by themselves did not lead to a statistically significant increase in BrdU incorporation compared with nonsense control. However, miR-335 alone or in combination with
miR-21 and/or -9 induced a statistically significant increase in BrdU incorporation (overall ANOVA, $F_{(6,28)}=4.82, p<0.01$; post hoc f-LSD, $p<0.01$ ), indicating that miR-335 acts as an ethanol-sensitive cell-cycle regulator.

\section{Identification and analysis of mRNA targets of ethanol-sensitive miRNAs}

We used the miRanda (Enright et al., 2003; John et al., 2004) (http://cbio.mskcc.org/), and TargetScan (version 3.1) (Lewis et al., 2003, 2005), (http://www.targetscan.org/) algorithms, to identify targets of the four ethanol-suppressed micro-RNAs. Targets identified by the miRanda algorithm were mapped using the University of California, Santa Cruz genome browser (Kent et al., 2002) (http://genome.ucsc.edu/). Computation analyses identified only two genes, Jag-1 (Jagged-1) and ELAVL2, which were targets of at least three of the four ethanol-sensitive miRNAs: miRNAs 335, 21, 153, for Jag-1 (Fig. 10a, supplemental Fig. 1, available at www.jneurosci.org as supplemental material), and 

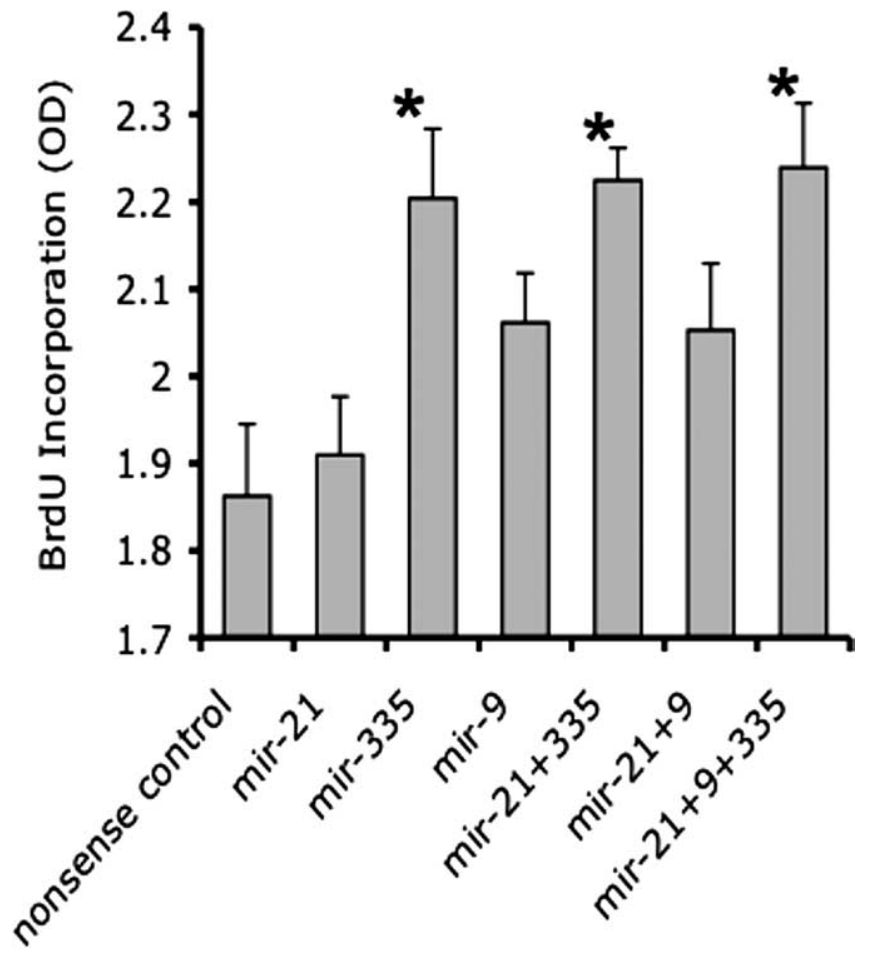

Treatment (miRNA knockdown)

Figure 9. BrdU incorporation was used to estimate the effect of miRNA knockdown on cell cycle. Cells were transfected with either nonsense control or various antisense anti-miRNA oligonucleotides, either alone or in combination, for a period of $24 \mathrm{~h}$ in the presence of culture medium containing BrdU. The $y$-axis depicts BrdU incorporation [in optical density (OD) units], whereas the $x$-axis depicts the various treatment conditions. Knockdown of miR-335 alone or in combination with miR-21 alone, or in combination with both miR-21 and miR-9, induced a significant increase in BrdU incorporation compared with nonsense controls. Data were based on six independent replicates and expressed as mean \pm SEM. Asterisks indicate statistical significance; $p$ values are as indicated in the text.

miRNAs 335, 153, and 9 for ELAVL2 (supplemental Fig. 2, available at www.jneurosci.org as supplemental material). Because both computational algorithms independently identified Jag-1 as a target of ethanol-sensitive miRNAs, whereas ELAVL2 was identified only by the miRanda algorithm, and because Jag- 1 was a shared target of both miR-335 and 21, our subsequent analysis focused on Jag-1.

We examined the effect of miRNA knockdown on Jag-1 mRNA expression. Real-time RT-PCR analysis (Fig. 10b) indicated that miR-335 knockdown, either alone or in combination with miR-21 did not lead to increased Jag-1 mRNA expression. However, combined knockdown of miR-335, -21, and -153 did induce a statistically significant, fourfold increase in Jag- 1 mRNA expression (ANOVA, $F_{(3,26)}=5.78, p<0.01$; post hoc f-LSD, $p<$ 0.01 ). Because ethanol suppressed miR-335, -21 , and -153 , we predicted that ethanol would induce expression of Jag-1 mRNA. Consistent with the above hypothesis, neurosphere cultures exposed to $320 \mathrm{mg} / \mathrm{dl}$ ethanol for $5 \mathrm{~d}$ exhibited a significant, 15-fold increase $\left(t_{(5)}=3.21 ; p<0.05\right)$ (Fig. 10c) in the expression of Jag-1 mRNA. Finally, because the miRanda algorithm also identified ELAVL2 as a potential target of three ethanol-sensitive micro-RNAs, we examined whether ethanol also regulated the expression of ELAVL2 mRNA. Ethanol at $320 \mathrm{mg} / \mathrm{dl}$ for $5 \mathrm{~d}$ led to a significant, 2.7-fold increase $\left(t_{(6)}=2.67 ; p<0.05\right)$ in ELAVL2 mRNA.

\section{Discussion}

Teratogens often disrupt the development of multiple tissues and organs. In the case of ethanol, these include the brain, heart, and craniofacies, among others (Sulik and Johnston, 1983; Daft et al., 1986). Even within a single tissue like the brain, ethanol regulates multiple genes, serving diverse cellular processes (Gottesfeld et al., 1990; Charness et al., 1994; Freund, 1994; Cheema et al., 2000; Heaton et al., 2000; Lindsley et al., 2006). The involvement of miRNAs as intermediaries may explain some of the teratogenic pleiotropism attributed to ethanol, simply because individual miRNAs regulate the stability and translation of large numbers of mRNAs serving varied biological processes. We examined ethanol's effect on miRNAs in fetal cerebral cortical-derived neuroepithelial cells, because these cells populate the cerebral cortex with neurons and are the source of the second-trimester growth spurt in brain mass (Dobbing and Sands, 1979; Caviness, 1982; Bayer and Altman, 1995; Takahashi et al., 1999).

\section{miRNA expression profiling}

Cerebral cortical neuroepithelial precursors expressed $\sim 40 \%$ of the sampled miRNAs, and these collectively constitute the miRNA signature that shapes their identity. Let-7 family members were the most highly expressed miRNAs, consistent with in vivo expression patterns reported by others (Krichevsky et al., 2003, 2006; Sempere et al., 2004), suggesting that the neurosphere culture model recapitulates critical aspects of normal brain development. Despite the importance of let-7 to embryogenesis (Hong et al., 1998; Pasquinelli and Ruvkun, 2002; Abrahante et al., 2003; Lin et al., 2003; Johnson et al., 2005), the let-7 family was not a significant ethanol target. Rather, the high dose of ethanol $(320 \mathrm{mg} / \mathrm{dl})$ suppressed moderately expressed miRNAs like miR-21, -335, -9, and -153. Such moderately expressed miRNAs preferentially suppress the expression of relatively rare mRNA transcripts (Lai, 2002; Pillai, 2005), and may shape the unique identity of the neuroepithelial transcriptome. Heavy ethanol consumption may therefore enhance the influence of rare mRNA transcripts on neuroepithelial fate by suppressing moderately expressed miRNAs. In contrast to the high ethanol dose, the lower ethanol dose $(60 \mathrm{mg} / \mathrm{dl})$ significantly increased miR335 , but not miR-21 expression. An additional implication of these studies is that low levels of ethanol consumption, attainable in social consumption settings, can also interfere with fetal development.

\section{Mechanisms mediating ethanol sensitivity of miRNAs}

Concurrent exposure to picrotoxin prevented ethanol suppression of miR-21 but not miR-335, suggesting that ethanol suppresses miR-21 via a $\mathrm{GABA}_{\mathrm{A}}$ receptor-dependent mechanism, whereas miR-335 was suppressed by a $G_{A B A}$-independent mechanism. Other ethanol response characteristics were also miRNA-specific. Methanol, a closely related alcohol, mimicked ethanol's effect on miR-21, but not miR-335 expression. Although it is possible that miR-21 is more sensitive to methanol than miR-335, analyses of the relationship between alcohol carbon chain length and toxicity indicate that methanol and ethanol exhibit similar dose-response profiles at biochemical and behavioral levels (Thompson and de Pomerai, 2005). A more parsimonious explanation is that miR-21 expression is regulated by partition of alcohols into the lipid bilayer and interaction with hydrophobic pockets within transmembrane domains of the $\mathrm{GABA}_{\mathrm{A}}$ receptor (Wick et al., 1998; Dwyer and Bradley, 2000), whereas miR-335 is regulated by another mechanism. 
The $\mathrm{GABA}_{\mathrm{A}}$ independence of miR-335 is somewhat surprising because GABA, like miR-335, regulates the cell cycle in the cortical neuroepithelium (Maric et al., 2001). However, the complex proximate chromosomal environment of the miR335 coding region may contribute to its ethanol sensitivity. miR-335 is coded within the second intron of a maternally imprinted, monoallelically expressed gene, mesoderm-specific transcript (MEST) (Lefebvre et al., 1998; Rodriguez et al., 2004). The MEST gene also codes for at least 17 alternate mRNAs (Rebhan et al., 1997) that can be transcribed from multiple transcription initiation sites, controlled by chromosome methylation at CpG islands (Nishita et al., 1999). Ethanol, because of its known ability to methylate DNA (Maier et al., 1999), may alter the complement of MEST pre-mRNA transcripts to favor those that do not include pre-miR-335. Support for this notion comes from literature showing that alternate mRNA isoforms of MEST are indeed generated when the cell cycle is deregulated (Pedersen et al., 2002), as occurs after ethanol exposure (Santillano et al., 2005).

\section{Functional analysis of} ethanol-sensitive micro-RNAs

miR-21 is coded within exon 12 of the gene for transmembrane protein-49/vacuole membrane protein-1, a Golgi-trafficking protein highly expressed in brain tissue (Rebhan et al., 1997; Shmueli et al., 2003). We report that suppression of miR-21 induced apoptosis, suggesting that miR-21 is an apoptosis repressor in neuroepithelial cells, as reported by others (Chan et al., 2005; Si et al., 2006). The proapoptotic effect of suppressing miR-21 was contrary to our previous data showing that cortical neuroepithelial cells were resistant to apoptosis after ethanol exposure (Santillano et al., 2005; Prock and Miranda, 2007). However, our data show that miR-335 knockdown prevents cell death caused by suppression of miR-21. Consequently, miR-335 is a functional antagonist to miR-21, and its suppression explains the resistance to apoptosis observed in ethanol-treated neuroepithelial cells. Furthermore, miR-335 suppression increased BrdU incorporation, and this increase was not reversed by concurrent administration of miR-21 or miR-9. These data suggest that miR-335 itself is an apoptosis permissive factor, and a cell cycle suppressor.

Interestingly, deletion of the paternal MEST allele leads to fetal and postnatal growth retardation (Lefebvre et al., 1998), an effect that appears to be antithetical to the function of its intronic miR335. It is possible that fetal growth is at least partly influenced by the competing influences of MEST and its cotranscribed miR335. As development proceeds, the brain remains one of the few tissues that continue to express high levels of MEST mRNA (Lefebvre et al., 1998). Moreover, miR-335 has also been detected on polyribosomes in maturing neurons (Kim et al., 2004), suggesting that miR-335 actively destabilizes protein translation from targeted mRNA transcripts. Therefore, the MEST/miR-335 gene locus is important for continued neuronal development in the fetal and neonatal brain.
In silico analyses indicate that miR-335 potentially targets 233 different mRNAs, whereas miR-21 may target up to 109 mRNAs (John et al., 2004). Importantly, miR-21 and miR-335 are estimated to coregulate the expression of only 3 of 342 identified genes, respectively (i.e., $>99 \%$ of the computationally identified genes are targeted independently by these two miRNAs). The implication of this extreme divergence in gene targets is unclear at this time. However, ethanol may provide a permissive context, which shapes cellular responses to other environmental agents. In complex, poly-teratogen environments, other agents may regulate alternate miRNAs, which nevertheless cooperate with ethanol-regulated miRNAs to further deregulate neural development.

Only two mRNAs, Jag-1 and ELAVL2, were identified as candidate targets of miR-335, along with at least two of the three other ethanol-sensitive miRNAs. Jag-1 mRNA was induced only when miR-335, -21, and -153 were coordinately suppressed, suggesting that mRNA transcript stability is cooperatively regulated by multiple miRNAs, rather than by changes in any single miRNA. Jag-1, a Notch ligand, promotes the proliferation of hematopoietic stem cells (Karanu et al., 2000) and neuroepithelial cells (Nyfeler et al., 2005), and, overall, Notch signaling appears to function as a brake, to delay neuronal differentiation (Lutolf et al., 2002). Importantly, converging evidence points to the Notch pathway as both a mediator and target of ethanol's actions. For example, deletion of the mammalian neuralized homolog leads to ethanol hypersensitivity (Ruan et al., 2001). Presenslin-1 deletion results in premature neuronal differentiation and suppression of miR-9 expression (Krichevsky et al., 2003), further supporting the involvement of the Notch pathway in ethanol's actions. 
In contrast to Jag-1, the brain-specific RNA binding protein ELAVL2, a presumptive target of miR-335, -153, and -9, promotes neuronal maturation by binding to the $3^{\prime}$ untranslated regions of mRNAs to suppress non-neuronal fates and promote neuronal identity (Akamatsu et al., 1999, 2005; Yano et al., 2005; Ratti et al., 2006). Previous evidence indicates that ELAVL2 also promotes neuron-specific alternate splicing (Zhu et al., 2006) and alternate polyadenylation (Zhu et al., 2007) to expand the transcriptome repertoire of neuron specific genes. These apparently antagonistic maturational roles of two ethanol-induced genes need additional investigation. Collectively, ethanolinduced genes may mediate aberrant maturation, consistent with a previously postulated role for ethanol in the proliferation and premature maturation of cortical stem and progenitor cells (Santillano et al., 2005).

\section{Conclusion}

Our evidence shows that a teratogen-like ethanol suppresses specific miRNAs in proliferating fetal cortical neuroepithelial precursors, and this suppression is partly $\mathrm{GABA}_{\mathrm{A}}$-receptor dependent. Ethanol-sensitive miRNAs behave both cooperatively and as functional antagonists to shape neuroepithelial survival and growth, and the coordinate suppression of miR-21 and miR-335 explains why ethanol drives proliferation rather than death of fetal cerebral cortical precursors. These data are consistent with a previous report indicating that neural development is determined by the coordinate regulation of multiple unrelated miRNAs (Krichevsky et al., 2006). Our data further indicate that ethanol-sensitive miRNAs control important developmental genes. We do not as yet know what intervening mechanisms connect the suppression of miRNAs to cell death and the cell cycle, although it is likely that Jag-1/Notch and ELAVL2 pathways contribute to ethanol's effects on neural stem cell maturation.

\section{References}

Abe K, Niikura Y, Misawa M (2004) $\mathrm{GABA}_{\mathrm{A}}$ receptor-mediated inhibition by ethanol of long-term potentiation in the basolateral amygdala-dentate gyrus pathway in vivo. Neuroscience 125:113-117.

Abrahante JE, Daul AL, Li M, Volk ML, Tennessen JM, Miller EA, Rougvie AE (2003) The Caenorhabditis elegans hunchback-like gene lin-57/hbl-1 controls developmental time and is regulated by microRNAs. Dev Cell 4:625-637.

Adachi J, Mizoi Y, Fukunaga T, Ogawa Y, Ueno Y, Imamichi H (1991) Degrees of alcohol intoxication in 117 hospitalized cases. J Stud Alcohol 52:448-453.

Akamatsu W, Okano HJ, Osumi N, Inoue T, Nakamura S, Sakakibara S, Miura M, Matsuo N, Darnell RB, Okano H (1999) Mammalian ELAVlike neuronal RNA-binding proteins $\mathrm{HuB}$ and $\mathrm{HuC}$ promote neuronal development in both the central and the peripheral nervous systems. Proc Natl Acad Sci USA 96:9885-9890.

Akamatsu W, Fujihara H, Mitsuhashi T, Yano M, Shibata S, Hayakawa Y, Okano HJ, Sakakibara S, Takano H, Takano T, Takahashi T, Noda T, Okano H (2005) The RNA-binding protein HuD regulates neuronal cell identity and maturation. Proc Natl Acad Sci USA 102:4625-4630.

Ambros V (2001) microRNAs: tiny regulators with great potential. Cell 107:823-826

Asyali MH, Alci M (2005) Reliability analysis of microarray data using fuzzy c-means and normal mixture modeling based classification methods. Bioinformatics 21:644-649.

Asyali MH, Shoukri MM, Demirkaya O, Khabar KS (2004) Assessment of reliability of microarray data and estimation of signal thresholds using mixture modeling. Nucleic Acids Res 32:2323-2335.

Bayer S, Altman J (1995) Neurogenesis and neuronal migration. In: The rat nervous system, Ed 2, pp 1041-1078. San Diego: Academic.

Bentwich I, Avniel A, Karov Y, Aharonov R, Gilad S, Barad O, Barzilai A, Einat P, Einav U, Meiri E, Sharon E, Spector Y, Bentwich Z (2005) Identifica- tion of hundreds of conserved and nonconserved human microRNAs 37:766-770.

Camarillo C, Kumar LS, Bake S, Sohrabji F, Miranda RC (2007) Ethanol regulates angiogenic cytokines during neural development: evidence from an in vitro model of mitogen-withdrawal-induced cerebral cortical neuroepithelial differentiation. Alcohol Clin Exp Res 31:324-335.

Caviness Jr VS (1982) Neocortical histogenesis in normal and reeler mice: a developmental study based upon $[3 \mathrm{H}]$ thymidine autoradiography. Brain Res 256:293-302.

Chan JA, Krichevsky AM, Kosik KS (2005) MicroRNA-21 is an antiapoptotic factor in human glioblastoma cells. Cancer Res 65:6029-6033.

Charness ME, Safran RM, Perides G (1994) Ethanol inhibits neural cell-cell adhesion. J Biol Chem 269:9304-9309.

Cheema ZF, Wade SB, Sata M, Walsh K, Sohrabji F, Miranda RC (1999) Fas/Apo [apoptosis]-1 and associated proteins in the differentiating cerebral cortex: induction of caspase-dependent cell death and activation of NF- $\kappa$ B. J Neurosci 19:1754-1770.

Cheema ZF, West JR, Miranda RC (2000) Ethanol induces Fas/Apo [apoptosis]-1 mRNA and cell suicide in the developing cerebral cortex. Alcohol Clin Exp Res 24:535-543.

Cheema ZF, Santillano DR, Wade SB, Newman JM, Miranda RC (2004) The extracellular matrix, p53 and estrogen compete to regulate cell-surface Fas/Apo-1 suicide receptor expression in proliferating embryonic cerebral cortical precursors, and reciprocally, Fas-ligand modifies estrogen control of cell-cycle proteins. BMC Neurosci 5:11.

Clarren SK (1986) Neuropathology in fetal alcohol syndrome. In: Alcohol and brain development (West JR, ed), pp 158-166. New York: Oxford UP.

Clarren SK, Alvord Jr EC, Sumi SM, Streissguth AP, Smith DW (1978) Brain malformations related to prenatal exposure to ethanol. J Pediatr 92:64-67.

Conaco C, Otto S, Han J, Mandel G (2006) Reciprocal actions of REST and a microRNA promote neuronal identity. Proc Natl Acad Sci USA 103:2422-2427.

Croce CM, Calin GA (2005) miRNAs, cancer, and stem cell division. Cell 122:6-7.

Daft PA, Johnston MC, Sulik KK (1986) Abnormal heart and great vessel development following acute ethanol exposure in mice. Teratology 33:93-104.

Denli AM, Hannon GJ (2003) RNAi: an ever-growing puzzle. Trends Biochem Sci 28:196-201.

Dobbing J, Sands J (1979) Comparative aspects of the brain growth spurt. Early Hum Dev 3:79-83.

Dwyer DS, Bradley RJ (2000) Chemical properties of alcohols and their protein binding sites. Cell Mol Life Sci 57:265-275.

Enright AJ, John B, Gaul U, Tuschl T, Sander C, Marks DS (2003) MicroRNA targets in Drosophila. Genome Biol 5:R1.

Freund G (1994) Apoptosis and gene expression: perspectives on alcoholinduced brain damage. Alcohol 11:385-387.

Goff LA, Yang M, Bowers J, Getts RC, Padgett RW, Hart RP (2005) Rational probe optimization and enhanced detection strategy for microRNAs using microarrays. RNA Biol 2:093-100.

Gottesfeld Z, Morgan B, Perez-Polo JR (1990) Prenatal alcohol exposure alters the development of sympathetic synaptic components and of nerve growth factor receptor expression selectivity in lymphoid organs. J Neurosci Res 26:308-316.

Heaton MB, Mitchell JJ, Paiva M, Walker DW (2000) Ethanol-induced alterations in the expression of neurotrophic factors in the developing rat central nervous system. Brain Res Dev Brain Res 121:97-107.

Hong Y, Roy R, Ambros V (1998) Developmental regulation of a cyclindependent kinase inhibitor controls postembryonic cell cycle progression in Caenorhabditis elegans. Development 125:3585-3597.

Houbaviy HB, Murray MF, Sharp PA (2003) Embryonic stem cell-specific microRNAs. Dev Cell 5:351-358.

Jiang J, Lee EJ, Gusev Y, Schmittgen TD (2005) Real-time expression profiling of microRNA precursors in human cancer cell lines. Nucl Acids Res 33:5394-5403.

John B, Enright AJ, Aravin A, Tuschl T, Sander C, Marks DS (2004) Human microRNA targets. PLoS Biol 2:e363.

Johnson SM, Grosshans H, Shingara J, Byrom MW, Jarvis R, Cheng AM, Labourier E, Reinert KL, Brown D, Slack FJ (2005) RAS is regulated by the let-7 microRNA family. Cell 120:635-647. 
Jones KL, Smith DW (1975) The fetal alcohol syndrome. Teratology 12:1-10.

Kalluri HS, Ticku MK (2002) Role of $\mathrm{GABA}_{\mathrm{A}}$ receptors in the ethanolmediated inhibition of extracellular signal-regulated kinase. Eur J Pharmacol 451:51-54.

Karanu FN, Murdoch B, Gallacher L, Wu DM, Koremoto M, Sakano S, Bhatia M (2000) The notch ligand jagged-1 represents a novel growth factor of human hematopoietic stem cells. J Exp Med 192:1365-1372.

Kent WJ, Sugnet CW, Furey TS, Roskin KM, Pringle TH, Zahler AM, Haussler D (2002) The human genome browser at UCSC. Genome Res 12:996-1006.

Kim J, Krichevsky A, Grad Y, Hayes GD, Kosik KS, Church GM, Ruvkun G (2004) Identification of many microRNAs that copurify with polyribosomes in mammalian neurons. Proc Natl Acad Sci USA 101:360-365.

Krek A, Grun D, Poy MN, Wolf R, Rosenberg L, Epstein EJ, MacMenamin P, da Piedade I, Gunsalus KC, Stoffel M, Rajewsky N (2005) Combinatorial microRNA target predictions 37:495-500.

Krichevsky AM, King KS, Donahue CP, Khrapko K, Kosik KS (2003) A microRNA array reveals extensive regulation of microRNAs during brain development. RNA 9:1274-1281.

Krichevsky AM, Sonntag KC, Isacson O, Kosik KS (2006) Specific microRNAs modulate embryonic stem cell-derived neurogenesis. Stem Cells 24:857-864.

Lai EC (2002) Micro RNAs are complementary to 3' UTR sequence motifs that mediate negative post-transcriptional regulation 30:363-364.

Lefebvre L, Viville S, Barton SC, Ishino F, Keverne EB, Surani MA (1998) Abnormal maternal behaviour and growth retardation associated with loss of the imprinted gene Mest. Nat Genet 20:163-169.

Lewis BP, Shih IH, Jones-Rhoades MW, Bartel DP, Burge CB (2003) Prediction of mammalian microRNA targets. Cell 115:787-798.

Lewis BP, Burge CB, Bartel DP (2005) Conserved seed pairing, often flanked by adenosines, indicates that thousands of human genes are microRNA targets. Cell 120:15-20.

Lim LP, Lau NC, Garrett-Engele P, Grimson A, Schelter JM, Castle J, Bartel DP, Linsley PS, Johnson JM (2005) Microarray analysis shows that some microRNAs downregulate large numbers of target mRNAs 433:769-773.

Lin SY, Johnson SM, Abraham M, Vella MC, Pasquinelli A, Gamberi C, Gottlieb E, Slack FJ (2003) The C. elegans hunchback homolog, hbl-1, controls temporal patterning and is a probable microRNA target. Dev Cell 4:639-650.

Lindsley TA, Miller MW, Littner Y, Bearer CF (2006) Signaling pathways regulating cell motility: a role in ethanol teratogenicity? Alcohol Clin Exp Res 30:1445-1450.

Loock C, Conry J, Cook JL, Chudley AE, Rosales T (2005) Identifying fetal alcohol spectrum disorder in primary care. CMAJ 172:628-630.

Lutolf S, Radtke F, Aguet M, Suter U, Taylor V (2002) Notch1 is required for neuronal and glial differentiation in the cerebellum. Development 129:373-385.

Ma W, Pancrazio JJ, Andreadis JD, Shaffer KM, Stenger DA, Li BS, Zhang L, Barker JL, Maric D (2001) Ethanol blocks cytosolic $\mathrm{Ca}^{2+}$ responses triggered by activation of $\mathrm{GABA}_{\mathrm{A}}$ receptor/ $\mathrm{Cl}^{-}$channels in cultured proliferating rat neuroepithelial cells. Neuroscience 104:913-922.

Maier SE, Cramer JA, West JR, Sohrabji F (1999) Alcohol exposure during the first two trimesters equivalent alters granule cell number and neurotrophin expression in the developing rat olfactory bulb. J Neurobiol 41:414-423.

Maric D, Liu QY, Maric I, Chaudry S, Chang YH, Smith SV, Sieghart W, Fritschy JM, Barker JL (2001) GABA expression dominates neuronal lineage progression in the embryonic rat neocortex and facilitates neurite outgrowth via $\mathrm{GABA}_{\mathrm{A}}$ autoreceptor $/ \mathrm{Cl}^{-}$channels. J Neurosci 21:2343-2360.

Nakamura M, Sekino Y, Manabe T (2007) GABAergic interneurons facilitate mossy fiber excitability in the developing hippocampus. J Neurosci 27:1365-1373.

Nishita Y, Sado T, Yoshida I, Takagi N (1999) Effect of CpG methylation on expression of the mouse imprinted gene Mest. Gene 226:199-209.

Noctor SC, Martinez-Cerdeno V, Ivic L, Kriegstein AR (2004) Cortical neurons arise in symmetric and asymmetric division zones and migrate through specific phases. Nat Neurosci 7:136-144.

Nyfeler Y, Kirch RD, Mantei N, Leone DP, Radtke F, Suter U, Taylor V (2005) Jagged1 signals in the postnatal subventricular zone are required for neural stem cell self-renewal. EMBO J 24:3504-3515.
Ostenfeld T, Svendsen CN (2004) Requirement for neurogenesis to proceed through the division of neuronal progenitors following differentiation of epidermal growth factor and fibroblast growth factor-2-responsive human neural stem cells. Stem Cells 22:798-811.

Owens DF, Liu X, Kriegstein AR (1999) Changing properties of $\mathrm{GABA}_{\mathrm{A}}$ receptor-mediated signaling during early neocortical development. J Neurophysiol 82:570-583.

Pagani F, Lauro C, Fucile S, Catalano M, Limatola C, Eusebi F, Grassi F (2006) Functional properties of neurons derived from fetal mouse neurospheres are compatible with those of neuronal precursors in vivo. J Neurosci Res 83:1494-1501.

Pasquinelli AE, Ruvkun G (2002) Control of developmental timing by microRNAs and their targets. Annual Rev Cell Dev Biol 18:495-513.

Pedersen IS, Dervan P, McGoldrick A, Harrison M, Ponchel F, Speirs V, Isaacs JD, Gorey T, McCann A (2002) Promoter switch: a novel mechanism causing biallelic PEG1/MEST expression in invasive breast cancer. Hum Mol Genet 11:1449-1453.

Petersen SL, Krishnan S, Hudgens ED (2006) The aryl hydrocarbon receptor pathway and sexual differentiation of neuroendocrine functions. Endocrinology 147:S33-S42.

Pillai RS (2005) MicroRNA function: multiple mechanisms for a tiny RNA? RNA 11:1753-1761.

Prock TL, Miranda RC (2007) Embryonic cerebral cortical progenitors are resistant to apoptosis, but increase expression of suicide receptor DISCcomplex genes and suppress autophagy following ethanol exposure. Alcohol Clin Exp Res 31:694-703.

Rakic P (1988) Specification of cerebral cortical areas. Science 241:170-176.

Ratti A, Fallini C, Cova L, Fantozzi R, Calzarossa C, Zennaro E, Pascale A, Quattrone A, Silani V (2006) A role for the ELAV RNA-binding proteins in neural stem cells: stabilization of Msil mRNA. J Cell Sci 119:1442-1452.

Rebhan M, Chalifa-Caspi V, Prilusky J, Lancet D (1997) GeneCards: encyclopedia for genes, proteins and diseases. Rehovot, Israel: Weizmann Institute of Science, Bioinformatics Unit and Genome Center. Retrieved July 23, 2007 from http://www.genecards.org/.

Riley EP, McGee CL (2005) Fetal alcohol spectrum disorders: an overview with emphasis on changes in brain and behavior. Exp Biol Med (Maywood) 230:357-365.

Rodriguez A, Griffiths-Jones S, Ashurst JL, Bradley A (2004) Identification of mammalian microRNA host genes and transcription units. Genome Res 14:1902-1910.

Ruan Y, Tecott L, Jiang MM, Jan LY, Jan YN (2001) Ethanol hypersensitivity and olfactory discrimination defect in mice lacking a homolog of Drosophila neuralized. Proc Natl Acad Sci USA 98:9907-9912.

Santillano DR, Kumar LS, Prock TL, Camarillo C, Tingling JD, Miranda RC (2005) Ethanol induces cell-cycle activity and reduces stem cell diversity to alter both regenerative capacity and differentiation potential of cerebral cortical neuroepithelial precursors. BMC Neurosci 6:59.

Schmittgen TD, Jiang J, Liu Q, Yang L (2004) A high-throughput method to monitor the expression of microRNA precursors. Nucl Acids Res 32:e43-.

Sempere L, Freemantle S, Pitha-Rowe I, Moss E, Dmitrovsky E, Ambros V (2004) Expression profiling of mammalian microRNAs uncovers a subset of brain-expressed microRNAs with possible roles in murine and human neuronal differentiation. Genome Biol 5:R13.

Shmueli O, Horn-Saban S, Chalifa-Caspi V, Shmoish M, Ophir R, BenjaminRodrig H, Safran M, Domany E, Lancet D (2003) GeneNote: whole genome expression profiles in normal human tissues. C R Biol 326:1067-1072.

Si ML, Zhu S, Wu H, Lu Z, Wu F, Mo YY (2006) miR-21-mediated tumor growth.

Sokol RJ, Delaney-Black V, Nordstrom B (2003) Fetal alcohol spectrum disorder. JAMA 290:2996-2999.

Streissguth AP, O’Malley K (2000) Neuropsychiatric implications and longterm consequences of fetal alcohol spectrum disorders. Semin Clin Neuropsychiatry 5:177-190.

Sulik KK, Johnston MC (1983) Sequence of developmental alterations following acute ethanol exposure in mice: Craniofacial features of the fetal alcohol syndrome. Am J Anat 166:257-269.

Takahashi T, Goto T, Miyama S, Nowakowski R, Caviness VJ (1999) Sequence of neuron origin and neocortical laminar fate: relation to cell cycle of origin in the developing murine cerebral wall. J Neurosci 19:10357-10371. 
Thompson G, de Pomerai DI (2005) Toxicity of short-chain alcohols to the nematode Caenorhabditis elegans: a comparison of endpoints. J Biochem Mol Toxicol 19:87-95.

Wade S, Oommen P, Conner W, Earnest D, Miranda R (1999) Overlapping and divergent actions of estrogen and the neurogrophins on cell fate and p-53 dependent signal transduction in conditionally immortalized cerebral cortical neuroblasts. J Neurosci 15 6994-7006.

Watson JB, Mednick SA, Huttunen M, Wang X (1999) Prenatal teratogens and the development of adult mental illness. Dev Psychopathol 11:457-466.

Wick MJ, Mihic SJ, Ueno S, Mascia MP, Trudell JR, Brozowski SJ, Ye Q, Harrison NL, Harris RA (1998) Mutations of gamma-aminobutyric acid and glycine receptors change alcohol cutoff: evidence for an alcohol receptor? Proc Natl Acad Sci USA 95:6504-6509.

Yanai J, Beer A, Huleihel R, Izrael M, Katz S, Levi Y, Rozenboim I, Yaniv SP,
Slotkin TA (2004) Convergent effects on cell signaling mechanisms mediate the actions of different neurobehavioral teratogens: alterations in cholinergic regulation of protein kinase $\mathrm{C}$ in chick and avian models. Ann NY Acad Sci 1025:595-601.

Yano M, Okano HJ, Okano H (2005) Involvement of Hu and heterogeneous nuclear ribonucleoprotein $\mathrm{K}$ in neuronal differentiation through $\mathrm{p} 21$ mRNA post-transcriptional regulation. J Biol Chem 280:12690-12699.

Yumiko H, Fujio M (2002) In vitro analysis of the origin, migratory behavior, and maturation of cortical pyramidal cells. J Comp Neurol 454:1-14.

Zhu H, Hasman RA, Barron VA, Luo G, Lou H (2006) A nuclear function of $\mathrm{Hu}$ proteins as neuron-specific alternative RNA processing regulators. Mol Biol Cell 17:5105-5114.

Zhu H, Zhou HL, Hasman RA, Lou H (2007) Hu proteins regulate polyadenylation by blocking sites containing U-rich sequences. J Biol Chem 282:2203-2210. 